\title{
Deuterium and Hydrogen Electrode Characteristics of Lithia-Silica Glasses
}

\author{
Donald Hubbard and Given W. Cleek
}

\begin{abstract}
The $\mathrm{pH}$ and $\mathrm{pD}$ responses of a series of lithia-silica glasses have been investigated and compared with the hygroscopicity, deuteroscopicity, and chemical durability of the glasses in aqueous and deuterium oxide buffers. The curves for $\mathrm{pH}$ and $\mathrm{pD}$ response as a function of composition pass through an optimum electrode response that is limited on the low percentage of silica end by poor chemical durability and a strong tendency to devitrif y upon reheating the glasses for the purpose of blowing the electrodes. The optimum also falls off on the high-silica end where opalescence appears and the hygro- and deuteroscopicities decrease.

The $\mathrm{pH}$ and $\mathrm{pD}$ response, hygroscopicity, and deuteroscopicity, as well as the chemical durability in aqueous and deuterium oxide solutions, appear to reflect some of the critical features of the $\mathrm{Li}_{2} \mathrm{O}-\mathrm{SiO}_{2}$ phase equilibrium diagram, with the optimum electrode response occurring in the composition range in which tridymite is the primary phase.

Indices of refraction and expansion data for these $\mathrm{Li}_{2} \mathrm{O}-\mathrm{SiO}_{2}$ glasses exhibit breaks at the same compositions indicated by the physicochemical properties.
\end{abstract}

\section{Introduction}

Electrodes prepared from silicate glasses whose compositions include substantial percentages of $\mathrm{Li}_{2} \mathrm{O}$ have become commercially accepted in recent years because of their favorable voltage response to hydrogen-ion activity in aqueous solutions over an extended range of $\mathrm{pH}$, alkaline salt concentrations, and temperature $[1$ to 4$] .{ }^{1}$ Considerable confusion, however, still prevails in the readily available literature concerning the use of $\mathrm{Li}_{2} \mathrm{O}$ in electrode glasses [5 to 10]. The present investigation was undertaken to ascertain whether a series of $\mathrm{Li}_{2} \mathrm{O}-\mathrm{SiO}_{2}$ glasses exhibited any unusual features in regard to the normal dependence of $\mathrm{pH}$ response upon the properties of suitable chemical durability and adequate hygroscopicity [11 to 13]. In addition, a study of the deuteroscopicity, ${ }^{2}$ chemical durability to deuterium oxide solutions, and the electrode response $(\mathrm{pD})$ of these $\mathrm{Li}_{2} \mathrm{O}-\mathrm{SiO}_{2}$ glasses to deuterium-ion activity were undertaken.

The experimental procedures employed for determining the deuteroscopicity, $\mathrm{pD}$ response, and the chemical durability to deuterium buffers of this series of glasses were similar to the procedures reported in previous investigations on other glass series for hygroscopicity, $\mathrm{pH}$ response, and chemical durability to aqueous solutions [11 to 13$]$.

\section{Hygroscopicity and Deuteroscopicity}

The hygroscopicity and deuteroscopicity values listed in table 1 and plotted in figure 1 were obtained on two series of $\mathrm{Li}_{2} \mathrm{O}-\mathrm{SiO}_{2}$ glasses. One of these series $(\bigcirc)$ was that studied for density and reported by Young and his colleagues [14]. Their glasses had been analyzed and carefully annealed by a cooling

1 Figures in brackets indicate the literature references at the end of this paper. 2 "Deuteroscopicity" is the expression applied to $\mathrm{D}_{2} \mathrm{O}$ sorption corresponding to the term "hygroscopicity." schedule designed to place each member of the series in a comparable condition. The hygroscopicity and deuteroscopicity composition curves for these glasses demonstrated abrupt changes at the same compositions indicated by the density composition curve [14] and by other hygroscopicity composition data obtained by a different procedure and reported in an earlier publication [15]. Data for index of refraction ${ }^{3}$ and expansion ${ }^{4}$ obtained on this same series of glasses are presented in table 2 and figure 2 because they emphasize the same composition features shown by the hygroscopicity and deuteroscopicity curves.

For all properties studied on this analyzed and carefully annealed series of glasses, including the amounts of $\mathrm{H}_{2} \mathrm{O}$ and $\mathrm{D}_{2} \mathrm{O}$ retained upon reheating at $110^{\circ} \mathrm{C}$ after the completion of the hygroscopicity and deuterescopicity experiments, distinct changes in the slopes are indicated near 82 and 77 percent of $\mathrm{SiO}_{2}$. The break at the higher percentage of $\mathrm{SiO}_{2}$ corresponds very closely to the eutectic composition between the compounds $\mathrm{Li}_{2} \mathrm{O} \cdot 2 \mathrm{SiO}_{2}$ and tridymite, while the other is approximately 2 percent lower in $\mathrm{SiO}_{2}$ than the transition point reported between $\mathrm{Li}_{2} \mathrm{O} . \mathrm{SiO}_{2}$ and $\mathrm{Li}_{2} \mathrm{O} .2 \mathrm{SiO}_{2}[19]$.

The compositions for the members of the new series of $\mathrm{Li}_{2} \mathrm{O}-\mathrm{SiO}_{2}$ glasses whose hygroscopicity and deuteroscopicity are plotted $(+)$ in figure 1 were calculated from the batch compositions. No definite schedule had been observed in cooling through the annealing range.

The exaggerated difference in the two series of glasses can probably be ascribed to the extent of the departure from randomness of the silica network. This is strongly supported by the fact that the lithiasilica glasses show a marked tendency to crystallize in the composition ranges in which $\mathrm{Li}_{2} \mathrm{O} . \mathrm{SiO}_{2}$ and $\mathrm{SiO}_{2}$ are the primary phases.

3 These index of refraction values were obtained by C. A. Faick, using an im mersion method [16, 17].

${ }^{4}$ These expansion data were taken by L. H. Maxwell, using the Saunders modified Fizeau interferometric procedure [18]. 


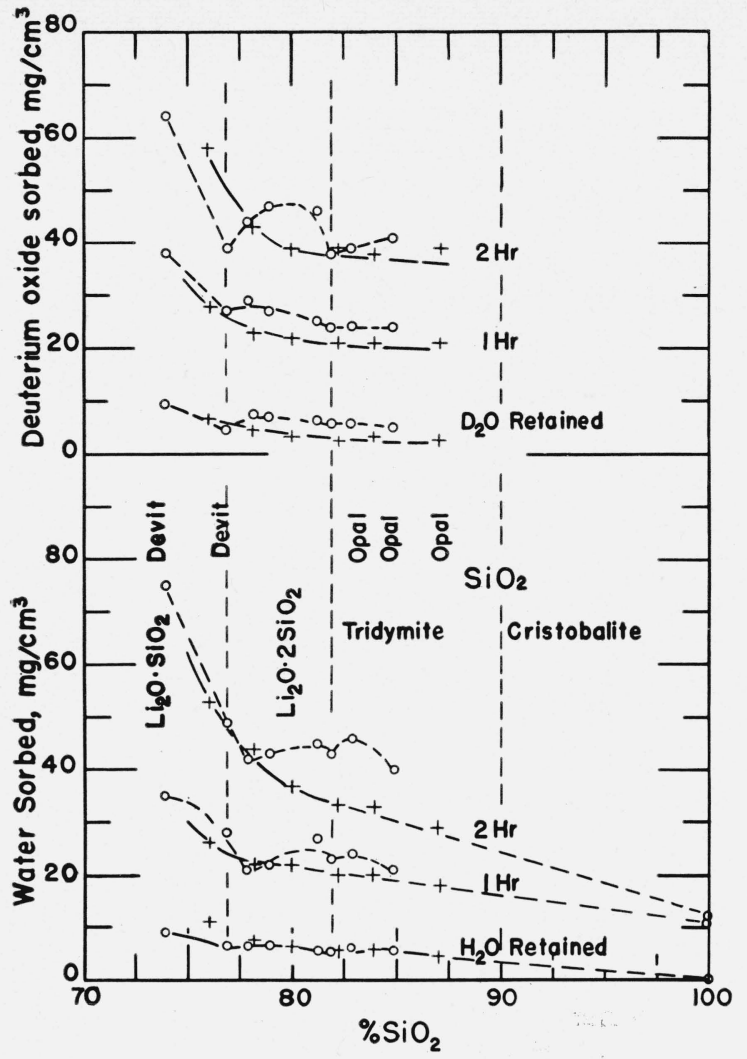

Figure 1. Hygroscopicity and deuteroscopicity of two series of $\mathrm{Li}_{2} \mathrm{O}-\mathrm{SiO}_{2}$ glasses.

$(0)$ glasses annealed and analyzed [14]; $(+)$, glasses having no definite annealing schedule and whose compositions were calculated from batch compositions.

TABLE 1. Hygroscopicity and deuteroscopicity of two series of $\mathrm{Li}_{2} \mathrm{O}-\mathrm{SiO}_{2}$ glasses

\begin{tabular}{|c|c|c|c|c|c|c|c|}
\hline \multicolumn{8}{|c|}{ A. Annealed and analyzed glasses of Young, Glaze, Faick, and Finn [14] } \\
\hline \multicolumn{2}{|c|}{ Glasses } & \multicolumn{3}{|c|}{ Water $\left(\mathrm{H}_{2} \mathrm{O}\right)$} & \multicolumn{3}{|c|}{ Deuterium oxide $\left(\mathrm{D}_{2} \mathrm{O}\right)$} \\
\hline $\mathrm{Li}_{2} \mathrm{O}$ & $\mathrm{SiO}_{2}$ & $\begin{array}{l}\text { Sorbed } \\
1 \mathrm{hr}\end{array}$ & $\begin{array}{l}\text { Sorbed } \\
2 \mathrm{hr}\end{array}$ & Retained & $\begin{array}{c}\text { Sorbed } \\
1 \mathrm{hr}\end{array}$ & $\begin{array}{c}\text { Sorbed } \\
2 \mathrm{hr}\end{array}$ & $\begin{array}{c}\mathrm{Re}- \\
\text { tained }\end{array}$ \\
\hline $\begin{array}{c}\% \\
26.13 \\
23.18 \\
22.20 \\
21.09 \\
18.73 \\
18.11 \\
17.05 \\
15.12\end{array}$ & $\begin{array}{c}\% \\
73.87 \\
76.82 \\
77.80 \\
78.91 \\
81.27 \\
81.89 \\
82.95 \\
84.88\end{array}$ & $\begin{array}{c}\mathrm{mg} / \mathrm{cm}^{3} \\
35 \\
27 \\
21 \\
22 \\
27 \\
23 \\
24 \\
21\end{array}$ & $\begin{array}{c}\mathrm{mg} / \mathrm{cm}^{3} \\
75 \\
49 \\
42 \\
43 \\
45 \\
43 \\
46 \\
40\end{array}$ & $\begin{array}{c}m g / \mathrm{cm}^{3} \\
8.8 \\
6.4 \\
6.5 \\
6.7 \\
5.5 \\
5.2 \\
6.0 \\
5.6\end{array}$ & $\begin{array}{c}\mathrm{mg} / \mathrm{cm} \mathrm{m}^{3} \\
38 \\
27 \\
29 \\
27 \\
25 \\
24 \\
24 \\
24\end{array}$ & $\begin{array}{c}\mathrm{mg} / \mathrm{cm}^{3} \\
64 \\
39 \\
44 \\
47 \\
46 \\
38 \\
39 \\
41\end{array}$ & $\begin{array}{c}\mathrm{mg} / \mathrm{cm}^{3} \\
9.7 \\
4.6 \\
7.7 \\
7.0 \\
6.1 \\
5.9 \\
5.9 \\
5.0\end{array}$ \\
\hline \multicolumn{2}{|c|}{ Fused $\mathrm{SiO}_{2}$} & 11 & 12 & 0 & - & -..- & -..-- \\
\hline \multicolumn{8}{|c|}{ B. Glasses whose compositions were calculated from the batch composition } \\
\hline $\begin{array}{l}23.9 \\
21.8 \\
20.0 \\
17.8 \\
16.1 \\
12.9\end{array}$ & $\begin{array}{l}76.1 \\
78.2 \\
80.0 \\
82.2 \\
83.9 \\
87.1\end{array}$ & $\begin{array}{l}26 \\
22 \\
22 \\
20 \\
20 \\
19\end{array}$ & $\begin{array}{l}53 \\
44 \\
37 \\
33 \\
33 \\
28\end{array}$ & $\begin{array}{r}11.0 \\
7.4 \\
6.3 \\
5.4 \\
5.9 \\
4.2\end{array}$ & $\begin{array}{l}28 \\
23 \\
22 \\
21 \\
21 \\
21\end{array}$ & $\begin{array}{l}57 \\
43 \\
39 \\
39 \\
38 \\
39\end{array}$ & $\begin{array}{l}6.9 \\
4.3 \\
3.4 \\
2.5 \\
3.1 \\
2.3\end{array}$ \\
\hline \multicolumn{2}{|c|}{ Corning 015 a } & 104 & 168 & -...-- & ---- & $-\cdots$ & $\cdots$ \\
\hline
\end{tabular}

a A commercial electrode glass included for comparison.

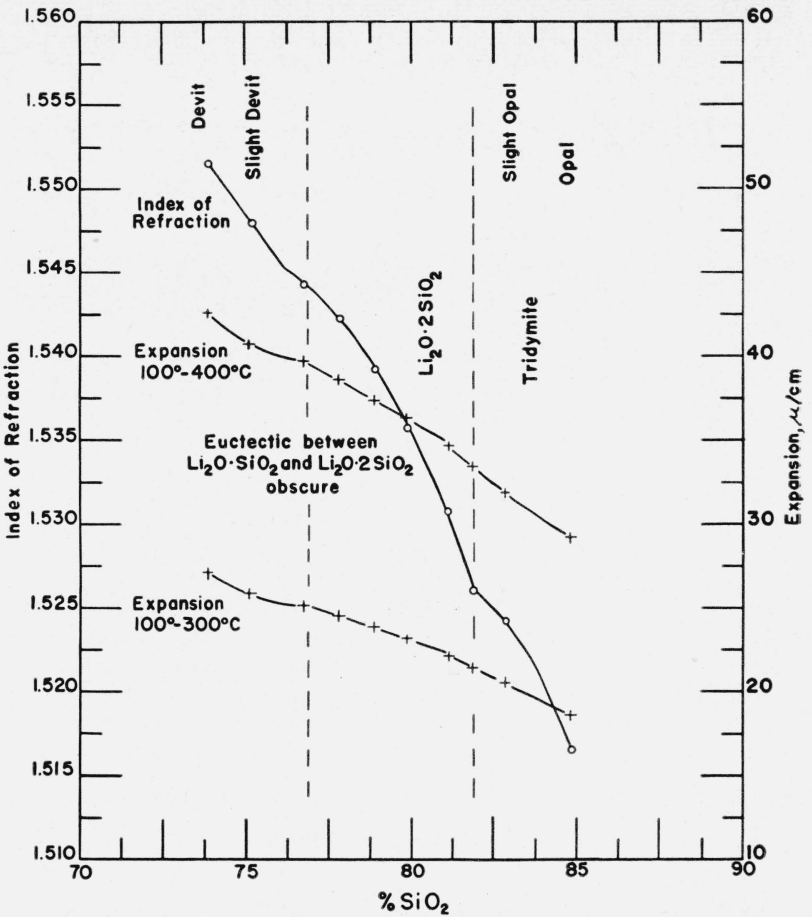

Figure 2. Indices of refraction and expansion characteristics of a series of $\mathrm{Li}_{2} \mathrm{O}-\mathrm{SiO}_{2}$ glasses.

TABLE 2. Index of refraction $(\mathrm{Na} \lambda=5889)$ and expansion characteristics of a series of $\mathrm{Li}_{2} \mathrm{O}-\mathrm{SiO}_{2}$ glasses

\begin{tabular}{|c|c|c|c|c|c|c|c|c|}
\hline \multicolumn{2}{|c|}{ Glasses } & \multicolumn{4}{|c|}{ Expansion } & \multirow{2}{*}{$\begin{array}{l}\text { Critical } \\
\text { temper- } \\
\text { ature }\end{array}$} & \multirow{2}{*}{$\begin{array}{l}\text { Soften- } \\
\text { ing } \\
\text { temper- } \\
\text { ature }\end{array}$} & \multirow{2}{*}{$\begin{array}{l}\text { Index of } \\
\text { refrac- } \\
\text { tion }\end{array}$} \\
\hline $\mathrm{Li}_{2} \mathrm{O}$ & $\mathrm{SiO}_{2}$ & $\begin{array}{c}100^{\circ} \\
\text { to } \\
300^{\circ} \mathrm{C}\end{array}$ & $\begin{array}{c}100^{\circ} \\
\text { to } \\
400^{\circ} \mathrm{C}\end{array}$ & $\begin{array}{l}100^{\circ} \\
\mathrm{CT}\end{array}$ & $\begin{array}{l}100^{\circ} \\
\mathrm{ST}^{\mathrm{b}}\end{array}$ & & & \\
\hline$\%$ & $\%$ & $\mu / \mathrm{cm}$ & $\mu / \mathrm{cm}$ & $\mu / \mathrm{cm}$ & $\mu / \mathrm{cm}$ & ${ }^{\circ} \mathrm{C}$ & ${ }^{\circ} \mathrm{C}$ & \\
\hline 26.13 & 73.87 & 27.1 & 42.6 & 50.7 & 60.7 & 445 & 475 & 1. 5515 \\
\hline 24.81 & 75.19 & 25.9 & 40.7 & 48.0 & 58. 0 & 445 & 475 & 1. 5480 \\
\hline 23.18 & 76.82 & 25.1 & 39.7 & 48.7 & 54.7 & 450 & 475 & 1. 5443 \\
\hline 22.20 & 77.80 & 24.5 & 38.6 & 48.5 & 56.0 & 460 & 485 & 1. 5423 \\
\hline 21.09 & 78.91 & 23.8 & 37.3 & 46.2 & 56.7 & 460 & 490 & 1. 5392 \\
\hline 20.06 & 79. 94 & 23.1 & 36.3 & 45.0 & 56.0 & 460 & 490 & 1. 5357 \\
\hline 18. 73 & 81. 27 & 22.1 & 34.7 & 44.1 & 46.6 & 465 & 480 & 1. 5307 \\
\hline 18.11 & 81.89 & 21.4 & 33.5 & 42.8 & 49.8 & 465 & 495 & 1. 5260 \\
\hline 17. 05 & 82.95 & 20.5 & 31.8 & 39.7 & 47.7 & 455 & 480 & 1. 5242 \\
\hline 15.12 & 84.88 & 18.6 & 29.2 & 36.7 & 43.2 & 460 & 490 & 1. 5165 \\
\hline \multicolumn{2}{|c|}{ Fused $\mathrm{SiO}_{2}$} & & & & & & & 1. 4567 \\
\hline
\end{tabular}

a CT, critical temperature. b $\mathrm{ST}$, softening temperature.

\section{Chemical Durability}

The chemical durabilities of the $\mathrm{Li}_{2} \mathrm{O}-\mathrm{SiO}_{2}$ glasses over an extended $\mathrm{pH}$ range are listed in table 3 and plotted in figure 3 . These durability data, obtained by an interferometer procedure [20,21], illustrate the familiar swelling in the acid range (represented as negative attack in the figure), and the usual solution of the glass in the alkaline buffers. These durability features are characteristic of many silicate glasses exposed to the Britton-Robinson universal buffer mixtures at $80^{\circ} \mathrm{C}$ [11 to 13$]$. 
TABLE 3. Chemical durability and $\mathrm{pH}$ response of $\mathrm{Li}_{2} \mathrm{O}-\mathrm{SiO}_{2}$ glasses in Britton-Robinson universal buffers

\begin{tabular}{|c|c|c|c|c|c|c|c|c|c|c|c|}
\hline \multicolumn{2}{|c|}{ Glasses a } & \multicolumn{6}{|c|}{ Chemical durability $\left(6 \mathrm{hr}, 80^{\circ} \mathrm{C}\right)$ at $\mathrm{pH}$} & \multicolumn{3}{|c|}{$\begin{array}{c}\mathrm{pH} \text { response, } 4.1 \text { to } 8.2 \\
\text { after soaking }\end{array}$} & \multirow{2}{*}{$\begin{array}{l}\text { Working } \\
\text { characteristics }\end{array}$} \\
\hline $\mathrm{Li}_{2} \mathrm{O}$ & $\mathrm{SiO}_{2}$ & 2.0 & 4.1 & 6.0 & 8.2 & 10.2 & 11.8 & $15 \mathrm{~min}$ & $6 \mathrm{hr}$ & $24 \mathrm{hr}$ & \\
\hline $\begin{array}{c}\% \\
23.9 \\
21.8 \\
20.0 \\
17.8 \\
16.1 \\
12.9\end{array}$ & $\begin{array}{c}\% \\
76.1 \\
78.2 \\
80.0 \\
82.2 \\
83.9 \\
87.1\end{array}$ & $\begin{array}{l}\quad \text { Fringes } \\
30 \text { swell. } \\
9 \text { swell } \\
11 / 2 \text { sewll } \\
1-\text { swell } \\
1 / 4 \text { swell } \\
1 / 10+\text { swell }\end{array}$ & $\begin{array}{l}\quad \text { Fringes } \\
30 \text { swell } \\
9 \text { swell } \\
11 / 2 \text { swell } \\
1 \text { - swell } \\
1 / 4 \text { swell } \\
1 / 10+\text { swell }\end{array}$ & $\begin{array}{l}\quad \text { Fringes } \\
30 \text { swell } \\
9 \text { swell } \\
11 / 2 \text { swell } \\
1 / 2+\text { swell } \\
1 / 4 \text { swell } \\
1 / 10+\text { swell }\end{array}$ & \begin{tabular}{l}
\multicolumn{1}{c}{ Fringes } \\
24 swell \\
9 swell \\
$2-$ swell \\
$1 / 2+$ swell-- \\
$2 / 10$ swell \\
D c swell-..
\end{tabular} & $\begin{array}{l}\text { Fringes } \\
\text { 30 attack } \\
6 \text { attack } \\
11 / 2 \text { attack } \\
\text { SC d } \\
\text { SC d } \\
\text { SC d }\end{array}$ & $\begin{array}{l}\text { Fringes } \\
72 \text { attack } \\
21 \text { attack } \\
7 \text { attack } \\
2 \text { attack } \\
11 / 2 \text { attack } \\
1+\text { attack }\end{array}$ & $\begin{array}{c}m v / \mathrm{pH} \\
(\mathrm{e}) \\
(\mathrm{e}) \\
32.5 \\
56.5 \\
57.5 \\
-. .-.\end{array}$ & $\begin{array}{c}m v / \mathrm{pH} \\
-0 .- \\
54.0 \\
57.5 \\
55.5\end{array}$ & $\begin{array}{c}m v / \mathrm{pH} \\
-\cdots \\
14.0 \\
44.5 \\
57.5 \\
55.5\end{array}$ & $\begin{array}{l}\text { Devitrified. } \\
\text { Slight devitrification. } \\
\text { Clear. } \\
\text { Do. } \\
\text { Slight opal. } \\
\text { Opal. }\end{array}$ \\
\hline \multicolumn{2}{|c|}{ Fused $\mathrm{SiO}_{2}$} & $\mathrm{ND} \mathrm{b}_{-}$ & $\mathrm{ND} \mathrm{b}_{-}$ & ND b.. & $\mathrm{ND} \mathrm{b}_{-}$ & ND b.. & $1 / 2$ attack & $(f)$ & (f) & $(\mathrm{f})$ & \\
\hline
\end{tabular}

a Series B of table 1. b ND, not detectable. o D, detectable. d SC, surface cut. • Devitrified. i No definite pH response.

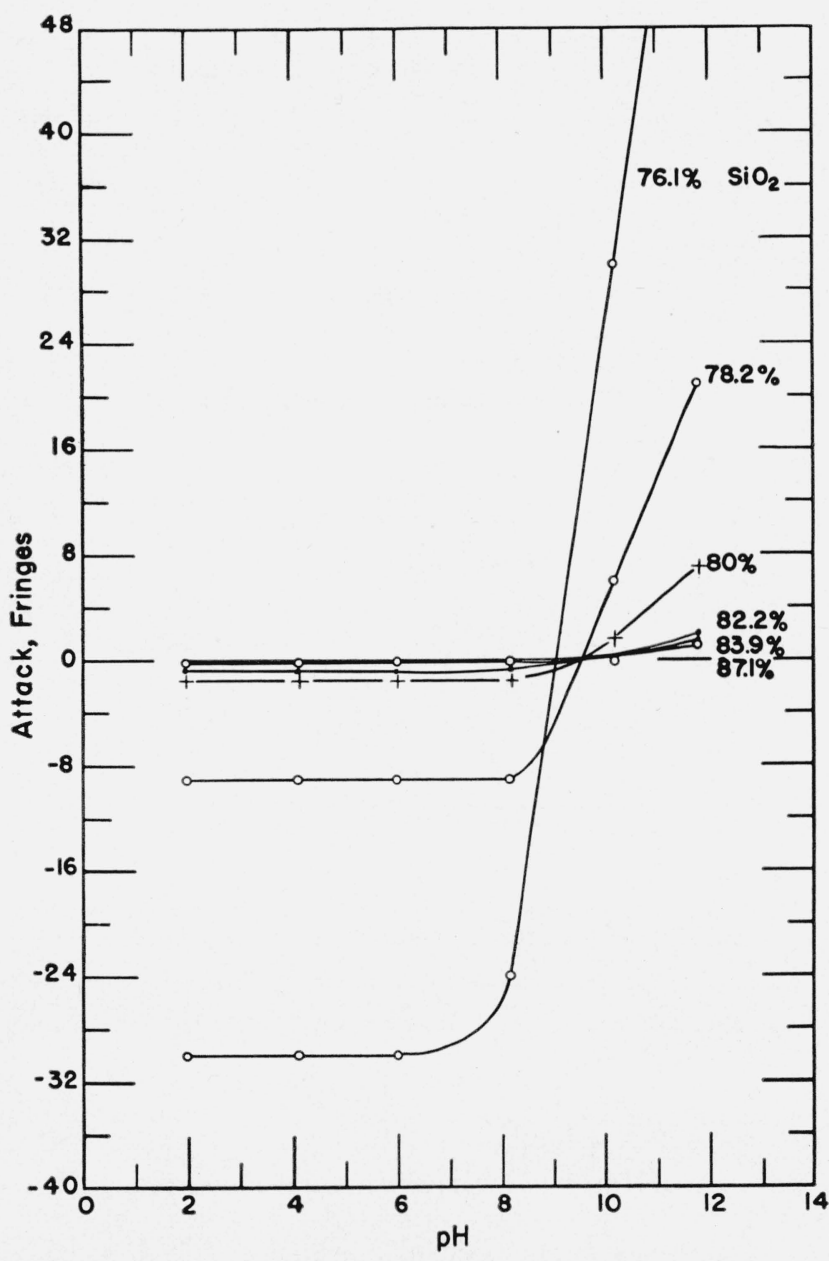

Figure 3. Chemical durability of $\mathrm{Li}_{2} \mathrm{O}-\mathrm{SiO}_{2}$ glasses.

Britton-Robinson universal buffer mixtures, 6 hours, $80^{\circ} \mathrm{C}$.

\section{Relation Between $\mathrm{pH}$ Response, Hygro- scopicity, and Chemical Durability}

An over-all picture of the dependence of $\mathrm{pH}$ response of the $\mathrm{Li}_{2} \mathrm{O}-\mathrm{SiO}_{2}$ glasses on their chemical durability and hygroscopicity is shown in figure 4. The pronounced decline in the chemical durability for members of this series having increased $\mathrm{Li}_{2} \mathrm{O}$

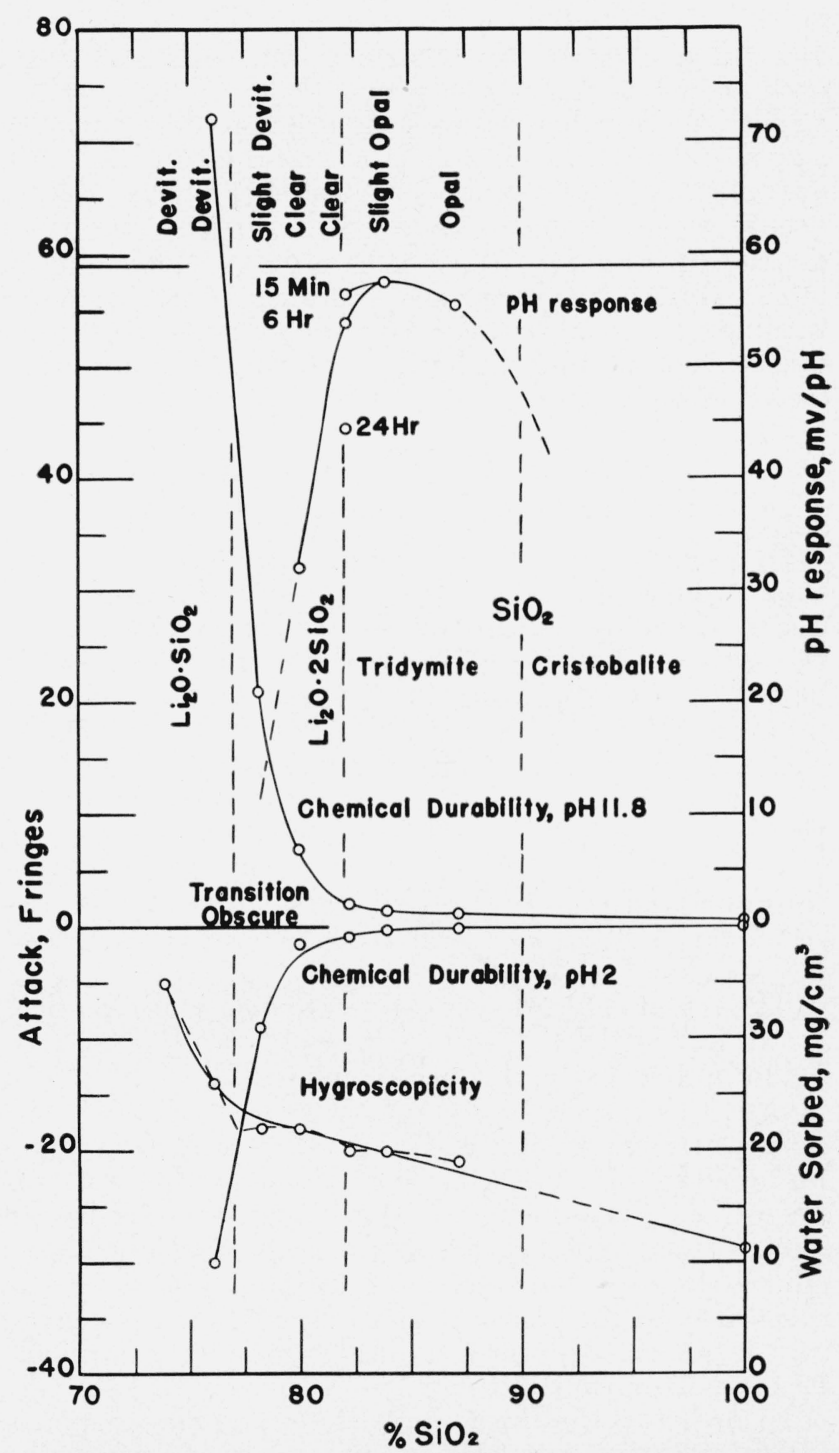

Figure 4. Comparison of the $\mathrm{pH}$ response, the hygroscopicity, and the chemical durability at $\mathrm{pH} 2$ and 11.8 of a series of $\mathrm{Li}_{2} \mathrm{O}-\mathrm{SiO}_{2}$ glasses.

The approximate compositions at which a new primary phase appears in the equilibrium diagram are indicated by vertical lines. Hygroscopicity values (1-hr exposure) are for glasses " $\mathrm{B}$ " table 1 , except for 73.8 percent $\mathrm{SiO}_{2}-$ two possible curves are drawn through the resulting eomposite data. 
content, as indicated by the curves for attack and swelling at $\mathrm{pH} 11.8$ and $\mathrm{pH} 2$, respectively, is associated with an equally pronounced failure in the $\mathrm{pH}$ response of electrodes prepared from these glasses. Although the composition range over which successful electrodes can be prepared is restricted by the appearance of coarse devitrification for the glasses of lower percentages of $\mathrm{SiO}_{2}$ upon reheating for the purpose of blowing the electrode bulbs, and by the appearance of opals in the higher $\mathrm{SiO}_{2}$ members, the $\mathrm{pH}$ response-composition curve obviously indicates an optimum similar to those found for all other series of glasses previously investigated [11, 12, 13].

The correspondence between the departures of the $\mathrm{pH}$ response-composition curve and some of the critical compositions of the phase equilibrium diagram is rather striking, with the optimum performance appearing in the composition range in which tridymite is the primary phase [19].

Perhaps the most interesting and possibly the most significant feature of these data is the fact that the optimum $\mathrm{pH}$ response for the $\mathrm{Li}_{2} \mathrm{O}-\mathrm{SiO}_{2}$ glasses occurs at much lower values of hygroscopicity than do the optima for $\mathrm{Na}_{2} \mathrm{O}-\mathrm{SiO}_{2}$ and $\mathrm{K}_{2} \mathrm{O}-\mathrm{SiO}_{2}$ glasses [13]. Whether this has any significant bearing on an ultimate acceptable theory for the glass electrode can only be ascertained in light of much additional data on other series of glasses.

\section{Comparison of $\mathrm{pD}$ Response and $\mathrm{pH}$ Response of $\mathrm{Li}_{2} \mathrm{O}-\mathrm{SiO}_{2}$ Glasses}

In an effort to obtain some information concerning the response of silicate glasses to deuterium ions, the difference in potential for electrodes prepared from the glasses of the $\mathrm{Li}_{2} \mathrm{O}-\mathrm{SiO}_{2}$ series was determined between two solutions of limited buffer capacity prepared from $\mathrm{D}_{2} \mathrm{O}$ by the use of $\mathrm{P}_{2} \mathrm{O}_{5}$ and $\mathrm{CaO}^{5}$ These materials were chosen because they did not introduce hydrogen ions, and at the same time they produced buffers, from inexpensive compounds, having a wide $\mathrm{pD}$ interval. The apparent values (obtained with a calibrated glass electrode) of the resulting buffers were $\mathrm{pD} 0.65$ for the $\mathrm{D}_{3} \mathrm{PO}_{4}$ and pD 12.4 for $\mathrm{Ca}(\mathrm{OD})_{2}$.

The results obtained for $\mathrm{pD}$ response and chemical durability of the $\mathrm{Li}_{2} \mathrm{O}-\mathrm{SiO}_{2}$ glasses in these deuterium oxide buffers are given in table 4 and plotted $(\bigcirc)$ in figure 5. A comparison of these results with the data obtained with the Britton-Robinson universal buffers (fig. 4) indicates that the response to deuterium ions is superior to the response to hydrogen ions. However, a glance at the respective durability curves reveals that there is a marked superiority in durability of the glasses, especially at high alkalinity, in the special deuterium buffers over the aqueous Britton-Robinson buffers.

In order to obtain a more rigorous comparison, a set of parallel experiments were performed using water buffers prepared with the same constituents and of equal concentration as the deuterium oxide

5 The deuterium oxide having a certified purity of 99.8 percent of $\mathrm{D}_{2} \mathrm{O}$ was obtained from stock available in the Bureau's Mineral Products Division, originally purchased from the Sturat Oxygen Co. of San Francisco, Calif., by permis sion of the Atomic Energy Commission.

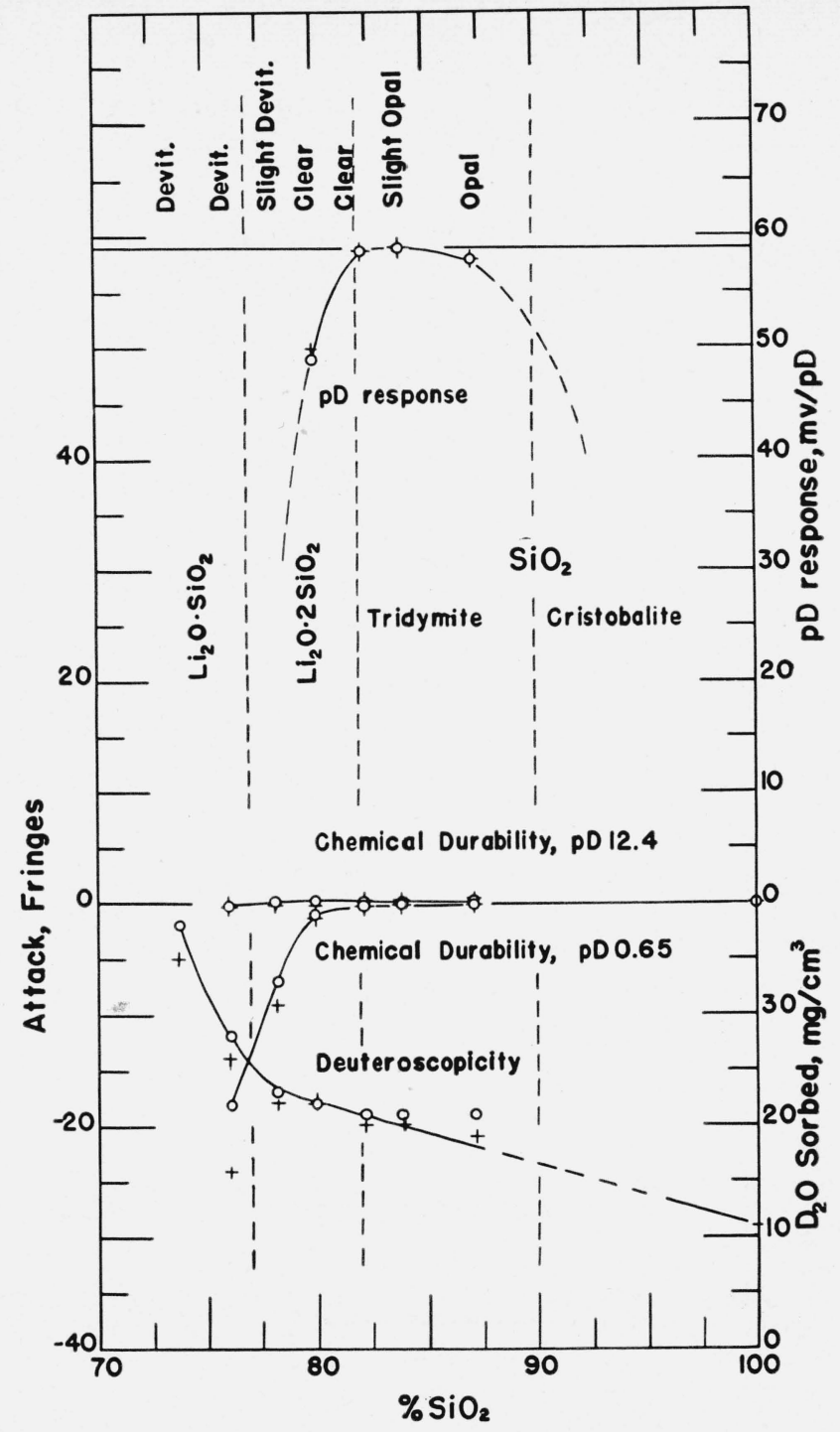

Figure 5. Performance of $\mathrm{Li}_{2} \mathrm{O}-\mathrm{SiO}_{2}$ glasses in $\mathrm{D}_{2} \mathrm{O}$ solutions compared with the performance in $\mathrm{H}_{2} \mathrm{O}$ solutions.

(o), the pD response and chemical durability in deuterium oxide solutions of $\mathrm{D}_{3} \mathrm{PO}_{4}, \mathrm{pD} 0.65$; and saturated $\mathrm{Ca}(\mathrm{OD})_{2}, \mathrm{pD} 12.4(+)$, the $\mathrm{pH}$ response and chemical durability in aqueous solutions of $\mathrm{H}_{3} \mathrm{PO}_{4}, \mathrm{pH} 0.65$ and saturated $\mathrm{Ca}(\mathrm{OH})_{2}, \mathrm{pH} 12.3$.

solutions (Data listed in table 4 and plotted $(+)$ in fig. 5.). When this was done, no significant differences in $\mathrm{pH}$ and $\mathrm{pD}$ response were detected. However, the impression remained that the electrode performances were slightly steadier in the deuterium oxide than in the aqueous solutions. In accordance with this, the amount of swelling observed in the acid deuterium oxide was less than in the corresponding aqueous solutions. It is also interesting to note that three of the glasses showed swelling in the saturated solution of $\mathrm{Ca}(\mathrm{OH})_{2}$ above $\mathrm{pH} 12$, while only one of them did so in the saturated solution of $\mathrm{Ca}(\mathrm{OD})_{2}$. It should also be pointed out that the saturated solution of $\mathrm{Ca}(\mathrm{OD})_{2}$ had an apparent $\mathrm{pD}$ approximately 0.1 of a unit higher than the $\mathrm{pH}$ of the $\mathrm{Ca}(\mathrm{OH})_{2}$. 
TABLE 4. $\mathrm{pH}$ and $\mathrm{pD}$ response, hygroscopicity, and deuteroscopicity, chemical durability in aqueous and deuterium oxide buffers prepared from $\mathrm{P}_{2} \mathrm{O}_{5}$ and $\mathrm{CaO}$, of a series of $\mathrm{Li}_{2} \mathrm{O}-\mathrm{SiO}_{2}$ glasses

\begin{tabular}{|c|c|c|c|c|c|c|c|c|c|}
\hline \multicolumn{10}{|c|}{ Glasses (B) table 1 , except for glass containing 73.87 percent of $\mathrm{SiO}_{2}$} \\
\hline \multicolumn{2}{|c|}{ Glasses } & \multicolumn{2}{|c|}{ Vapor sorbed $1 \mathrm{hr}$} & \multicolumn{2}{|c|}{$\begin{array}{l}\text { Electrode response } \\
\text { between- }\end{array}$} & \multicolumn{4}{|c|}{ Chemical durability (attack) } \\
\hline $\mathrm{Li}_{2} \mathrm{O}$ & $\mathrm{SiO}_{2}$ & $\mathrm{H}_{2} \mathrm{O}$ & $\mathrm{D}_{2} \mathrm{O}$ & $\begin{array}{l}\mathrm{pH} 0.65 \\
\text { and } 12.3\end{array}$ & $\begin{array}{l}\text { pD } 0.65 \\
\text { and } 12.4\end{array}$ & $\mathrm{H}_{3} \mathrm{PO}_{4} \mathrm{pH} 0.65$ & $\begin{array}{c}\mathrm{D}_{3} \mathrm{PO}_{4} \text { Apparent } \\
\text { pD } 0.65\end{array}$ & $\mathrm{Ca}(\mathrm{OH})_{2} \mathrm{pH} 12.3$ & $\begin{array}{c}\mathrm{Ca}\left(\mathrm{OD}_{2}\right) \text { Apparent } \\
\text { pD } 12.4\end{array}$ \\
\hline$\%$ & $\%$ & $\mathrm{mg} / \mathrm{cm}^{3}$ & $\mathrm{mg} / \mathrm{cm}^{3}$ & $m v / \mathrm{pH}$ & $m o / \mathrm{pD}$ & Fringes & Fringes & Fringes & Fringes \\
\hline 26. 13 & 73.87 & 35 & 38 & (a) & -...... & -...... & 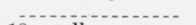 & & - \\
\hline 23.9 & 76.1 & 26 & 28 & (a) & .......... & 24 swell & 18 swell_ & 1/4 swell, pitted_-. & $1 / 10$ swell. \\
\hline 21.8 & 78.2 & 22 & 23 & (b) & - & 9 swell & 7 swell & Swell, pitted & $1 / 4$ attack. \\
\hline 20 & 80 & 22 & 22 & 50 & 49 & $1+$ swell ........ & 1 swell & 1/4 swell, pitted & $1 / 4-$ attack. \\
\hline 17.8 & 82.2 & 20 & 21 & 58. 7 & 58.7 & $1 / 4$ swell & $1 / 4$ - swell $\ldots . .$. & $2 / 10$ attack & 2 10 attack. \\
\hline 16.1 & 83.9 & 20 & 21 & 59 & 59 & $2 / 10-$ swell $\ldots$ & 1 1́10 swell & $1 / 10$ attack & $1 / 10$ attack. \\
\hline 12.9 & 87.1 & 19 & 21 & 58 & 58 & $\mathrm{D}^{\mathrm{d}}$ swell ........ & $D^{d}$ swell .............. & $1 / 10$ attack & $1 / 10-$ attack. \\
\hline \multirow{2}{*}{\multicolumn{2}{|c|}{$\begin{array}{l}\text { Fused } \mathrm{SiO}_{2} \ldots \\
\text { Corning } 015\end{array}$}} & 11 & & (c) & (c) & NDe swell_.... & NDe swell. ..... & 2/10 attack $\ldots$ & $1 / 10+$ attack. \\
\hline & & 104 & 111 & 58.4 & 58.1 & $2 / 10$ swell & Dd swell . . . . & $1 / 4-$ attack & $2 / 10$ attack. \\
\hline
\end{tabular}

a Devitrified while blowing electrodes. b Slight devitrification. ' No definite electrode response. d D, detectable. e ND, not detectable.

\section{Lithium Ion Response of Electrodes Pre- pared From $\mathrm{Li}_{2} \mathrm{O}-\mathrm{SiO}_{2}$ Glasses}

The question is often raised concerning the equilibritive response of glass electrodes to positive ions other than hydrogen, especially to ions common to both the solution and to the glass. In the present case the response to lithium ions of an electrode prepared from the lithium silicate glass $\left(\mathrm{Li}_{2} \mathrm{O}, 12.9 \%\right.$; $\mathrm{SiO}_{2}, 87.1 \%$ ) was determined over the range pLi 1 to 3 in solutions containing $\mathrm{LiNO}_{3}$ to which $1 \mathrm{ml}$ of glacial acetic acid per $50 \mathrm{ml}$ of solution was added to maintain a constant $\mathrm{pH}$ during the observations. If one assumes that all of the voltage change observed between the glass electrode and the saturated calomel reference cell over this pLi range can be attributed to the response of the glass electrode to $\mathrm{Li}^{+}$ions, the $\mathrm{pLi}$ response of the $\mathrm{Li}_{2} \mathrm{O}-\mathrm{SiO}_{2}$ glass was less than $1 \mathrm{mv}$ per pLi. For all practical purposes it can be stated that a pLi response of electrodes prepared from this $\mathrm{Li}_{2} \mathrm{O}-\mathrm{SiO}_{2}$ glass is essentially absent, whereas a full $\mathrm{pH}$ and $\mathrm{pD}$ response is present.

It would be interesting to extend these investigations to a study of the response of the glass electrode to tritium ions.

\section{Summary}

The $\mathrm{pH}$ and $\mathrm{pD}$ response of electrodes prepared from a series of $\mathrm{Li}_{2} \mathrm{O}-\mathrm{SiO}_{2}$ glasses have been compared with the hygroscopicity, dueteroscopicity, and chemical durability of the glasses in aqueous and deuterium oxide buffers. The curves for $\mathrm{pH}$ and $\mathrm{pD}$ response as a function of composition passed through an optimum electrode response that was limited on the low-silica end by poor chemical durability and a strong tendency toward devitrification of the glasses while the electrodes were being blown. The optimum also fell off on the bigh-silica end where opalescence appeared and the hygroscopicities and deuteroscopicities decreased. The optimum electrode performance was attained by those glasses that most nearly approximated the properties of
Corning 015. However, this optimum appeared at lower sorption values than were found for Corning 015 and other glass systems previously investigated.

Electrodes prepared from the $\mathrm{Li}_{2} \mathrm{O}-\mathrm{SiO}_{2}$ glasses apparently respond to deuterium ions as readily as to hydrogen ions.

In the present experiments the $\mathrm{Li}_{2} \mathrm{O}-\mathrm{SiO}_{2}$ glasses showed detectably more swelling in the acid qaueous than in the acid deuterium oxide solutions. Interesting examples of swelling in alkaline buffers above $\mathrm{pH}$ and $\mathrm{pD}$ values of 12 were observed. The apparent $\mathrm{pD}$ values for saturated $\mathrm{Ca}(\mathrm{OD})_{2}$ were slightly higher than for the corresponding $\mathrm{Ca}(\mathrm{OH})_{2}$ buffer.

The $\mathrm{pH}$ and $\mathrm{pD}$ response, hygroscopicity, and deuteroscopicity, as well as the chemical durabilities. in aqueous and deuterim oxide solutions, appear to reflect some of the critical features of the $\mathrm{Li}_{2} \mathrm{O}-\mathrm{SiO}_{2}$ phase-equilibrium diagram with the optimum electrode response occurring in the composition range in which tridymite is the primary phase.

\section{References}

[1] Henry H. Cary, Warren P. Baxter, U. S. Patent 2,462,843 March 1949.

[2] G. A. Perley, U. S. Patent 2,444,845, July 1948.

[3] G. A. Perley, Composition of $\mathrm{pH}$ responsive glasses, Anal. Chem. 21, 391 (1949).

[4] G. A. Perley, $\mathrm{pH}$ response of glass electrodes, Anal. Chem. 21, 559 (1949).

[5] D. A. MacInnes and M. Dole, The behaviour of glass electrodes of different compositions, J. Am. Chem. Soc. 52, 29 (1930).

[6] S. I. Ssokolof and A. H. Passynsky, On glass electrodes, Z. physik. Chem. 160A, 366 (1932).

[7] J. L. Gabbard and M. Dole, Additional notes on the glass electrode: I. Glass electrode errors at $30^{\circ}$ C; II. Properties of lithium glass electrodes, Trans. of Electrochem. Soc. 7\%, 129 (1937).

[8] Malcolm Dole, The glass electrode, (John Wiley \& Sons, Inc., New York, N. Y. 1941).

[9] Malcolm Dole, Recent advances in the theory and use of glass electrodes for $\mathrm{pH}$ determinations. Symposium on $\mathrm{pH}$ measurements, ASTM Technical Publication No. 73 , p. 45 (1946).

[10] G. A. Perley, Discussion. Symposium on $\mathrm{pH}$ measurements, ASTM Technical Publication No. 73, p. 55 (1946). 
[11] Donald Hubbard, Given W. Cleek, and Gerald F. Rynders, Electrode function ( $\mathrm{pH}$ response), hygroscopicity, and chemical durability of $\mathrm{Na}_{2} \mathrm{O}-\mathrm{CaO}-\mathrm{SiO}_{2}$ glasses, J. Research NBS 44, 247 (1950) RP2076.

[12] Donald Hubbard, Mason H. Black, and Gerald F. Rynders, Electrode function ( $\mathrm{pH}$ response), hygroscopicity, and chemical durability of soda-lead oxidesilica glasses, J. Research NBS 45, 430 (1950) RP2154.

[13] Donald Hubbard, Mason H. Black, Sylvanus F. Holley, and Gerald F. Rynders, Electrode function ( $\mathrm{pH}$ response), hygroscopicity and chemical durability of soda-potash-silica glasses, J. Research NBS 46, 168 (1951) RP2189.

[14] J. C. Young, F. W. Glaze, C. A. Faick, and A. N. Finn, Density of some soda-potash-silica glasses as a function of the composition, J. Research NBS 22, 453 (1939) RP1197.

[15] Donald Hubbard, Hygroscopicity of optical glasses as an indicator of serviceability, J. Research NBS 36,511 (1946) RP1719.

[16] C. A. Faick and A. N. Finn, The index of refraction of some soda-lime-silica glasses as a function of the composition, J. Am. Cer. Soc. 14, 518 (1931).
[17] C. A. Faick and Bernard Fonoroff, A precision apparatus for the rapid determination of indices of refraction and dispersion by immersion, J. Research NBS 32, 67 (1944) RP1575.

[18] J. B. Saunders, Improved interferometric procedure with application to expansion measurements, J Research NBS 23, 179 (1939) RP1227.

[19] F. C. Kracek, System $\mathrm{SiO}_{2}-2 \mathrm{Li}_{2} \mathrm{O} \cdot \mathrm{SiO}_{2}$, J. Phys. Chem. 34 (2) 2645 (1930).

[20] E. Berger, Grundsatzliches uber die chemische angreifbarkeit von glasen I. Glastech. Ber. dent. chem. Ges. 14, 351 (1936).

[21] Donald Hubbard, Edgar H. Hamilton, and Alfred N. Finn, Effect of the solubility of glass on the behavior of the glass electrode, J. Research NBS 22, 339 (1939) RP1187.

Washington, June 16, 1952 